International Journal of Instruction e-ISSN: 1308-1470 • www.e-iji.net

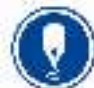

April 2021 • Vol.14, No.2

p-ISSN: 1694-609X

рр. 83-102

Article submission code:

20200210085603

Received: $10 / 02 / 2020$

Revision: 27/08/2020
OnlineFirst: 11/01/2021
Accepted: 20/09/2020

\title{
A Model of Lecturer Performance Evaluation: Sustainable Lecturer Performance Mapping
}

Trie Hartiti Retnowati

Prof., Yogyakarta State University, Indonesia, trie_hr@uny.ac.id

Djemari Mardapi

Prof., Yogyakarta State University, Indonesia, djemari@uny.ac.id

Badrun Kartowagiran

Prof., Yogyakarta State University, Indonesia, kartowagiran@uny.ac.id

Syukrul Hamdi

Dr., Yogyakarta State University, Indonesia, syukrulhamdi@uny.ac.id

Sustainable lecturer performance mapping needed a valid evaluation model. The absence of such a model brings about lecturer performance evaluation which was neither systematic nor sustainable. The study aimed to develop a valid and reliable model of lecturer performance evaluation. This research was a development research model. The model developed in the study has two components, namely: (1) computer application containing instrument to measure the lecturer performance, scoring guide, accomplishment criteria and their syntax; and (2) the user's guide for the application. The lecturer performance instruments were analyzed using content validity and construct validity. The instrument's content validity was proven by Aiken Formula, while the construct validity by Confirmatory Factor Analysis (CFA) and the instrument's reliability was estimated by Cronbach Alpha Formula. MANOVA was used as the hypothesis test of the implementation toward the models among the faculties. The result of trials on the model showed that all items of the instrument had met the content validity standard of 0.73 , the construct of the lecturer performance instrument in learning (planning, process, and assessment) was in good categories. The results showed that the lecturer performance evaluation model was valid, reliable, and comprehensive. The results also showed that the performance of the Faculty of Math and Science lecturers in learning was the highest.

Keywords: evaluation model, instrument, lecturer performance, lecturer, evaluation

\section{INTRODUCTION}

The changes happening in society has a big affect on education (Mohammadi \& Moradi, 2017). The global change in the field of education caused by the tremendous change in

Citation: Retnowati, T. H., Mardapi, D., Kartowagiran, B., \& Hamdi, S. (2021). A Model of Lecturer Performance Evaluation: Sustainable Lecturer Performance Mapping. International Journal of Instruction, 14(2), 83-102. https://doi.org/10.29333/iji.2021.1426a 
technology, globalization, and human mobility has changed the expectation in the educational system (Dzelzkaleja \& Kapenieks, 2018). This was confirmed by Van Hong, Tuyen, \& Luong, (2018) who revealed that 21st-century teachers and lecturers were required to have at least three competencies, one of which was the ability to apply technology in learning. It was in line with by Jones (2018) acknowledging that the $21^{\text {st }}$ century education prioritizes the development of social and individual, as well as adequate competences are completed by critical thinking, creativity, adaptability, and entrepreneurial abilities.

One level of education must use technology in higher education. Higher education is expected not only to be a place for students to learn but also to be an instrument for supporting the development of human civilization. Therefore, higher education, which is one of the important chains of education, is required to improve quality (infrastructure, lecturers, education personnel, students) continuously so that it can respond to the societies' needs for changes.

The quality in question includes the quality of infrastructure, lecturers, education personnel, students, and other supporting qualities. Lecturers as a determinant of the quality of a higher education service system are obligated to be able to manage their professional duties. Lecturers are professional educators and scholars who have a leading responsibility to transform, develop, and disseminate science, technology, and arts through teaching, research, and community service programs. Blankenau, Dorhout, \& Mason (2014) stated that a lecturer needed to be evaluated for his or her contribution to teaching, research, and community empowerment. The duty of a lecturer is very substantial that to be a lecturer, one has to be highly competent according to the above definition. It is in line that the lecturer's role in a university becomes influential. The study by Nurdiyanto \& Vem (2015) showed that lecturer performance was affected by teaching, research, community service, and Personality. It becomes particularly important that the lecturer's role regarding their quality of performance should be maintained.

So important is lecturers' role that the quality of their performance must be maintained. Amstrong (2000), Jones, Jenkin \& Lord (2006) states that Performance is the total of behaviors shown by a worker. Thus, a lecturer's performance is his accomplishment of the duties that become his responsibility under his competence, experience, and seriousness in a certain period.

The Law on Teachers and Lecturers of the Republic of Indonesia sets that lecturers commit to improve and develop their academic qualification and competence sustainably following the development in science, technology, and arts. Lecturers are required not only to implement the three dharma of higher education but also to improve their capacities in academic qualification and competence in their fields of expertise. Therefore, it needed to measured predictors of overall lecturer performance. Knowing the predictors of overall lecturer performance would help the lecturer and university identified the specific areas for improving the performance of the lecturer (Sok-Foon., Sze-Yin, \& Yin-Fah, 2012). 
The studies and regulations mentioned above show that lecturer performance is the main factor in maintaining the quality of education. When lecturer performance is well maintained, the outcome of educational processes will always be of high quality. For this condition to realize, a continual evaluation of lecturer performance is needed to get the most current information on lecturer performance condition, with the hope that the decreasing lecturer performance will be known soon and accurate solution to it can be given. Personality and dedication, professional development, teaching ability, relationship and communication, work climate, discipline, welfare, positive and significant relationship with the community towards the performance of lecturers by 97\%.(Suherman, et.al.,2019)

Performance in the learning process is an important lecturer's performance, so this research focuses on this. Lecturers are expected to be able to develop the potential of students, especially in critical thinking, this is according to Abrami, et.al. (2015) who conducted a meta-analysis of 341 studies that used an experimental and quasiexperimental approach about strategies to teach students to think critically. Abrami, et.al. (2005) found that providing opportunities for dialogue, allowing students to deal with problems, providing examples of critical thinking, and providing guidance to students will have a positive impact on critical thinking skills. Besides the strategy of learning, and assessment also took an essential part in the learning process.

According to Reeves (2010) assessment can also be used to improve the learning process. The assessment technique used is authentic, so that the results are comprehensive. This is in line with Brown, Irving, \& Keegan (2014) who state that authentic assessment techniques can demonstrate the natural condition of students. On the other hand, Earl, Hargreaves, \& Schmidt (2002) describe the results of their research that: (1) teachers prefer to use authentic assessments because the instruments used do not have to be tested first; (2) authentic assessment can build collaborative understanding between teachers, students, and parents because this technique assesses each student's activities by sometimes involving parents. Therefore the factors of learning performance in this study are divided into three stages, namely the planning stage, implementation stage, and the evaluation stage. Besides, the quality of information obtained by the teacher is also a determining factor for lecturer performance. This is in line with research by Tahir, Haming, \& Bijaang, (2018), who found that lecturer performance is affected by several factors including the quality of media information. According to Pramudyo, (2010). the factors that influence performance are motivation, competency, leadership, and work environment. This opinion is reinforced by Aoun, (2017) who states that it takes three new literacies in the R.I 4.0 era, namely technological literacy, data literacy, and human literacy. Accessibility of information, Accessibility of information, Information dissemination conducted by universities, Load information owned by the university, Accuracy of information produced. Therefore, the instrument in this study also includes the use of media by lecturers.

Based on the explanation and opinion of the experts, it showed that the performance of lecturers in learning became essential to be evaluated sustainably by valid and reliable 
instruments. The results of the lecturer performance evaluation were not only used to describe the performance of each lecturer but also used to foster the lecturer's performance comprehensively and sustainably.The strength of this study compared to other researches is the comprehensiveness instrument developed for lecturers who are dedicated to the fields of research, education and community empowerment. Besides that, this study is WEB-based research fitted by the need of $21^{\text {st }}$ century.

Blankenau, Dorhout, and Mason (2014) recommended that lecturer performance be conducted annually to evaluate the performance in teaching, research, and community service, which were able to be accompanied by other documents related to academic publication. Hence, this is the ground base for researchers to develop a lecturer performance evaluation model that was able to provide accurate, reliable, and easy to be used as the information since it was equipped with web-based applications.

\section{METHOD}

\section{Type of Research}

The research was development research aimed at developing a valid and reliable model of lecturer performance evaluation. The model developed in this study has two components, namely: (1) computer application containing instrument to measure the lecturer performance, scoring guide, accomplishment criteria and their syntax; and (2) the user's guide for the application. The trial was conducted in two stages. Phase 1 is an instrument trial to measure lecturer performance, stage 1 trial results were used to analyze the quality of the instrument in terms of readability, and stage 2 was a trial of computer applications and guidelines for the use of the application. The data from the results of the Phase 2 trial were used to determine the quality of the instrument using further analysis, namely confirmatory factor analysis and tested the effectiveness of the models that had been developed.

\section{Population and Sample}

The population at the trial of stage 1 was lecturers and students from 43 departments at Yogyakarta State University. The trial sample of this stage was 147 lecturers and 1470 undergraduate students who were decided using stratified random sampling techniques. The lecturer performance instrument developed was validated with content validity and construct validity. Content validity was measured using expert judgment followed by the Aiken formula, while construct validity was measured using exploratory factor analysis followed by confirmatory factor analysis. Instrument reliability was estimated using Cronbach Alpha. The trial of stage 1 also resulted in the lecturer's performance scores. Meanwhile, the trial sample of stage 2 was 60 lecturers randomly selected from the trial sample of stage 1 . The sample trial of stage 2 was instructed to read the guide carefully then answered the questions derived from the application.

\section{Instrument and Data Analysis Technique}

The instrument used was the lecturer performance instrument. The construct of the instructor's performance instruments in the learning presented in Table 1. 
Table 1

The construct of the instructor's performance instruments in the learning aspects

\begin{tabular}{llll}
\hline No & Factor & Respondent & Number of Items \\
\hline 1 & Planning & & \\
\cline { 1 - 2 } 2 & Process & Student & 30 \\
\hline 3 & Assessment & & \\
\hline
\end{tabular}

The data in this study consisted of two types, namely data obtained through lecturer performance instruments (which are already valid and reliable) and data measured using a model. The analysis of the content validity of the model of the lecturer performance evaluation was done by using Aiken $\mathrm{V}$. The validation of the instrument construct of lecturer performance in teaching was conducted by using the Confirmatory Factor Analysis (CFA), while its reliability estimate was measured by using Cronbach Alpha. The results of the use of models in each of the faculties were analyzed using the Multivariate Analysis of Variants (MANOVA) to determine the differences and the effectiveness of the models that had been developed.

\section{FINDINGS}

\section{The Construct of the Instrument and the Result of the Trial}

The results of the existing literature review showed that the constructs of lecturers' performance instruments in the learning included the planning, process, assessment factors. Then, the instrument was validated using content validity techniques by the expert judgment followed by the Aiken formula. The result of trials on the model showed that all items of the instrument had required the content validity standard of 0.73 .

Next, lecturers' performance instruments in the learning were analyzed using confirmatory factor analysis. The analysis could be processed because of the quite large number of respondents counting for 1470 students

Figure 1 presents the results of construct validity on the lecturer's performance instrument in the learning activities. 


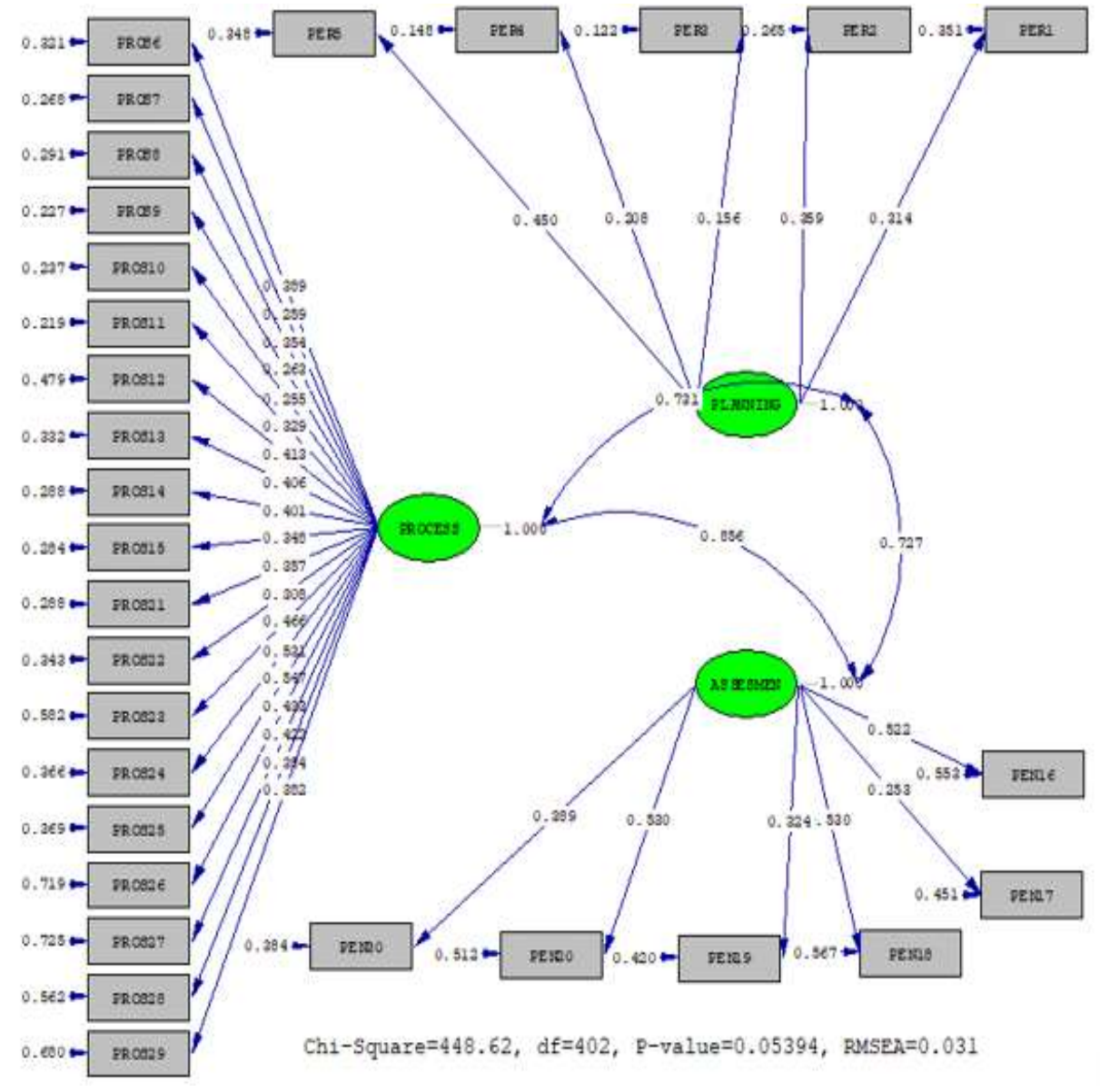

Figure 1

Standardized solution

Figure 1 showed that the construct of the lecturer's performance instrument on the learning is fit (supported by data), with Chi-square <2df, p-value $>0.05$, RMSEA $<0.08$, and GFI $>0.90$. In Figure 1, it could also be seen that all variables were observable (all items made a significant contribution to latent variables). I was indicated by the score of the loading factor (path coefficient) of all observable variables on latent variables more than 0.4 .

The determination of the reliability of the instrument construct of the lecturer's performance in teaching used the loading factor of each indicator which made the instrument $(\lambda)$ and unique error index of each indicator $(\delta)$, with the following formula (Geldhof, Preacher, \& Zyphur, 2014). 


$$
C R=\frac{\left(\sum_{i=1}^{i} \lambda_{i}\right)^{2}}{\left(\sum_{i=1}^{i} \lambda_{i}\right)^{2}+\left(\sum_{i=1}^{i} \delta\right)}
$$

The cut-off level for stating that the construct reliability was quite good is 0.7 (Bernstein, I. H., 2010, Nunnally, J.C. (1964). The reliability of the construct of the three stages with the number of items of 30 was 0.918 . It meant that the three stages of teaching, consisting of planning, process, and assessment contributed to a reliable estimation.

\section{The Result of the Trial the Result of Performance Lecturer in Learning}

The performance of the lecturer in learning was assessed based on students' perceptions. The lecturer's performance measured was divided into three stages, namely the planning stage, process stage, and assessment stage. Figure 2 presents the data on the results of lecturers 'performance according to students' perceptions.

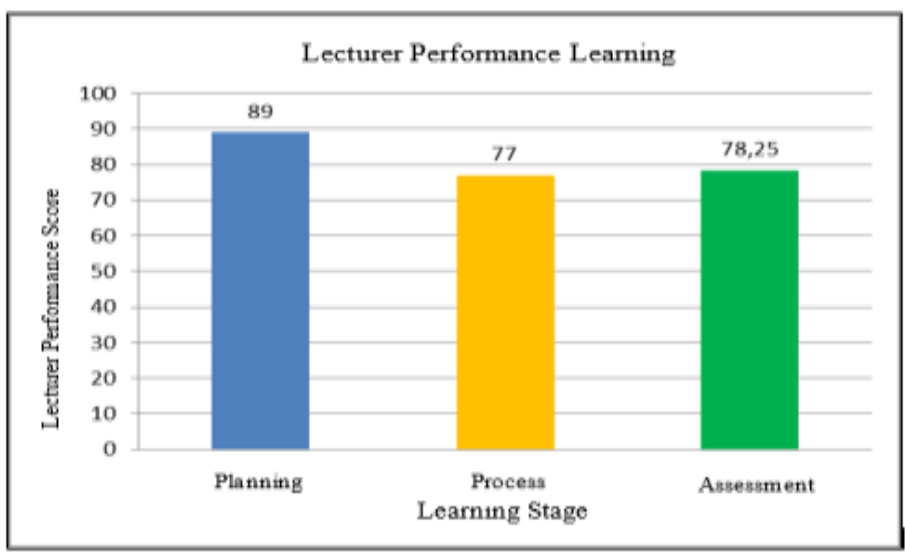

Figure 2

Lecturer performance profile in learning

Figure 2 showed the average of lecturer performance according to the students' perspective at each stage of learning. Based on Figure 2, it could be seen that the average score of lecturer performance in the planning stage was 89.00 , the process stage was 77.00 and the assessment stage was 78.25. The lecturer's performance in the planning stage was in a very good category, then the process and assessment stage were in a good category.

Furthermore, it was necessary to put attention on the average scores of lecturers' performance in every aspect of each learning stage according to the student's perspective. Each of the learning stages consisted of several aspects that should be done by the lecturer. All aspects at each stage needed to be evaluated. Lecturer performance 
would be optimal if all stages were done well. The results of the study supported research conducted by Harisantoso (2012) which revealed that overall of the lecturer's performance on pedagogical and professional competencies was good. Sumardjoko, (2010) revealed that to improve lecturers' roles in quality assurance in higher education, it is necessary to develop visionary leadership, firm organization culture, competent lecturers' support, and high achievement motivation.

\section{1) Lecturer Performance in Lesson Planning}

Lesson planning was a stage requiring lecturers to have the skills to initiate learning (opening) in lecturing activities. This stage was carried out by the lecturer to create a learning atmosphere so that students were physically and mentally prepared to make their attention focused on the material which will be learned. At the beginning of the lectures, some students had not had mental readiness and an interest in the lecture activities. Therefore, the skill to welcome at the beginning was one of the key points to success in the lecture activities. The lesson planning stage in evaluating lecturer performance consisted of six aspects. Each aspect of the lesson planning stage of learning is explained in Figure 3.

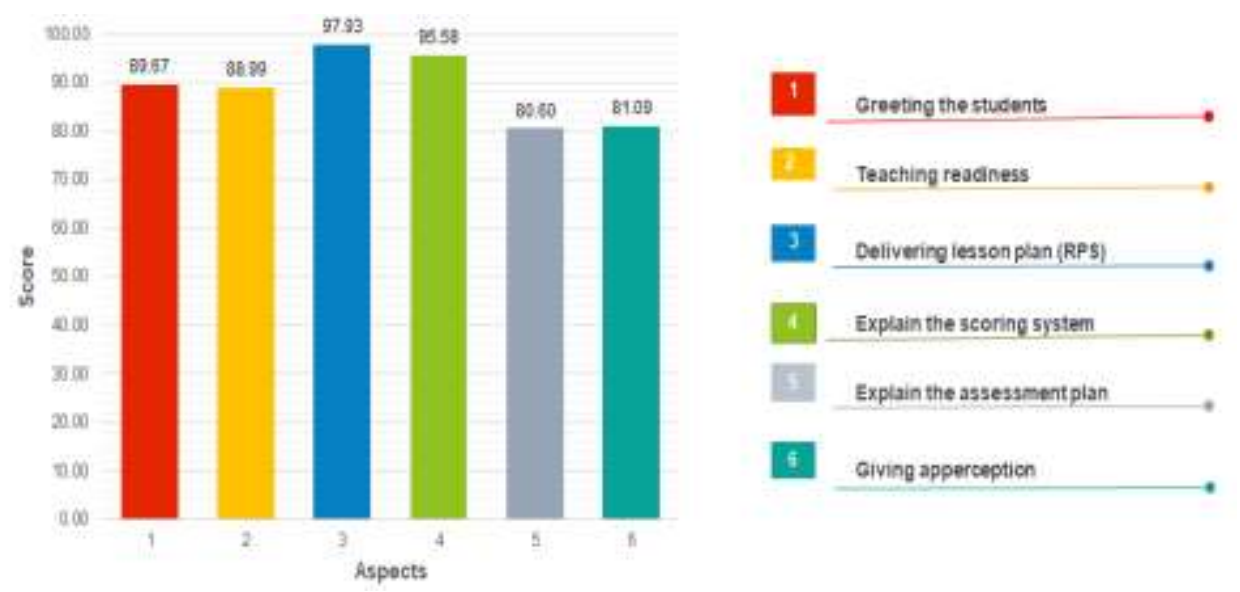

Figure 3

Lecturer performance in lesson planning

In Figure 3, it was known that the lecturer's performance in all aspects was in the range of 80.60 (the lowest) to 97.93 (the highest). It can be interpreted that the lecturer's performance in all aspects of the lesson planning stage is in a good category (score <80). The results of this study were in line with the research conducted by Harisantoso (2012) on evaluating lecturer performance. It was found that the seriousness of lecturers in lesson planning is in a very good category ( score $=86.3 \%$ ). 


\section{2) Lecturer Performance in the Learning Process}

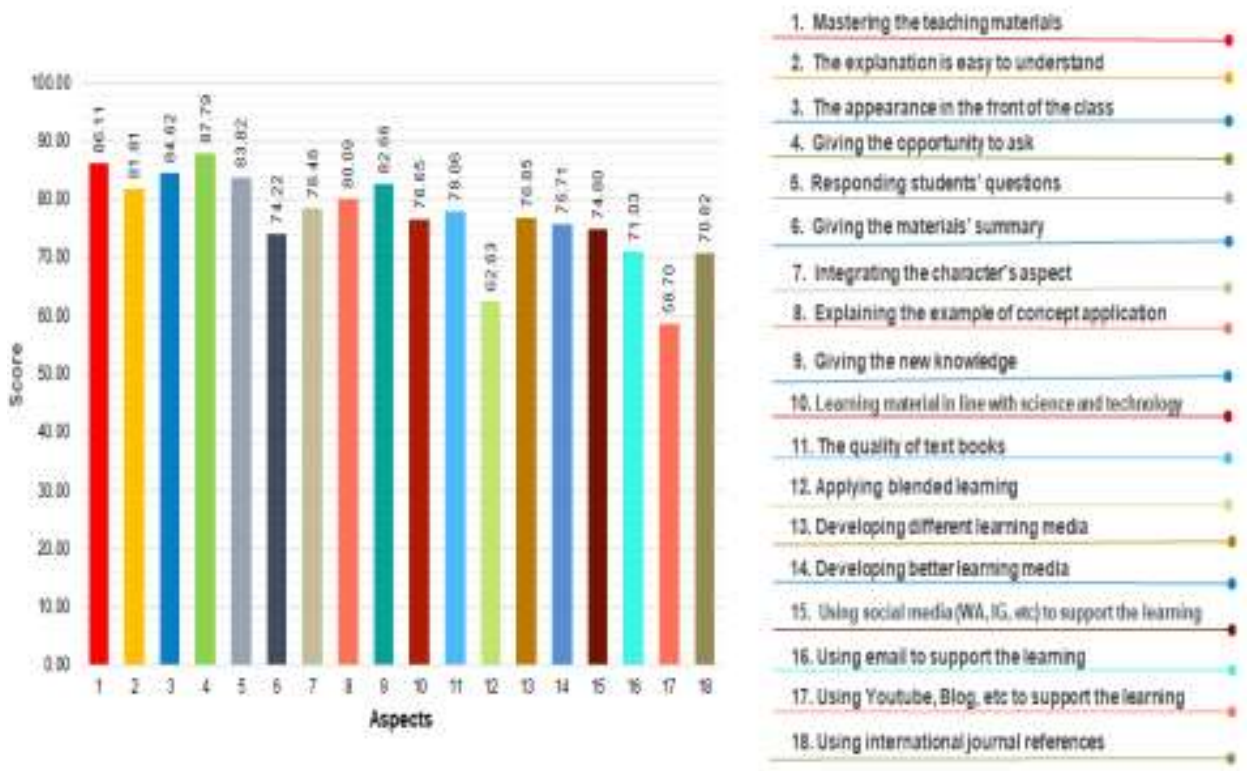

Figure 4

Lecturer performance in the learning process

In Figure 4, it showed that the performance of lecturers on the learning process was in a good category. However, when concerning in every aspect, in the learning process stage, there were still aspects having a score of less than 65 (aspects numbers 12 and 17). The aspect of number 12 was the aspect of using blended learning in lecture activity. It showed a score counting for 62.63. It can be interpreted that there are still many lecturers who did not use the blended learning method in the lecture process. In addition to aspect number 12, aspect number 17 (the use of youtube or blogs to support lecture activities) remained low. It was evidenced by a score of 56.70 in the aspect. The aspect showed the lowest score on the lecturer performance at the learning process stage.

\section{3) Lecturer Performance in Learning Assessment}

Assessment is one of the most important stages in lecturing activities. The level of student learning ability was known through assessments conducted by lecturers. The assessment results provided information about students' weaknesses in learning. Furthermore, lecturers used the results of the assessment as a consideration to make improvements to further lecture activities. Besides, assessments/ evaluations conducted by lecturers were able to be used to motivate students to study more diligently. Therefore, assessment activities were important to be carried out by lecturers in learning. Figure 5 presents the lecturer's performance at the learning assessment stage. 


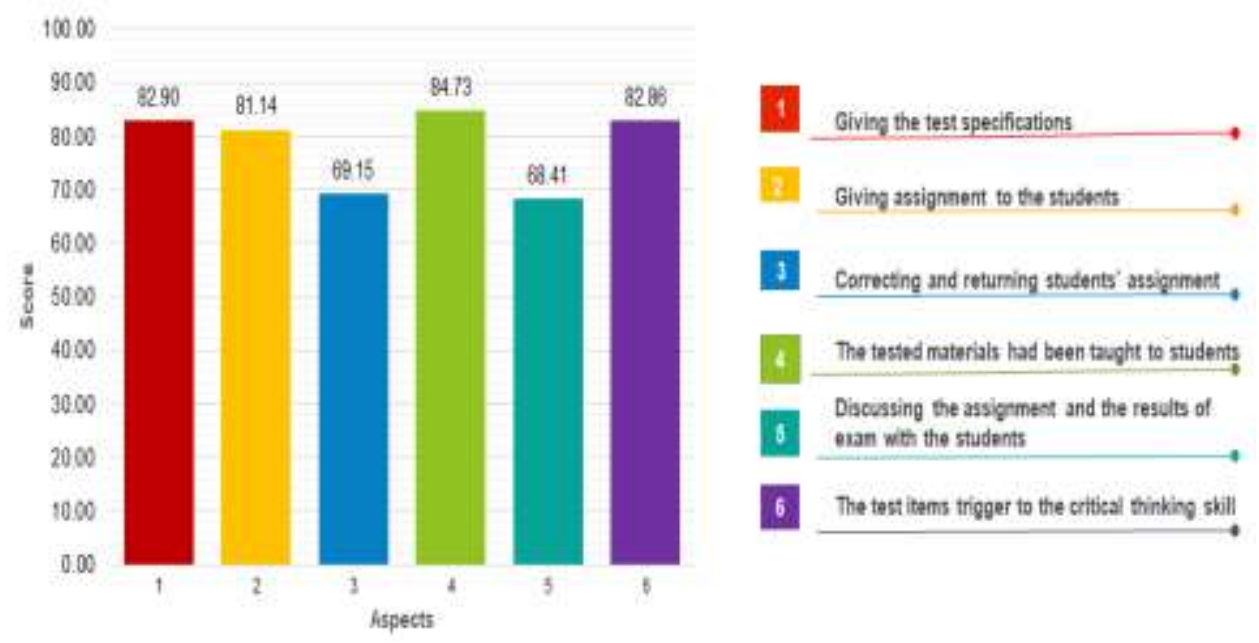

Figure 5

Lecturer performance in learning assessment

Based on Figure 5, it can be seen that at the assessment stage, the lecturer's performance consisted of six aspects. Overall, lecturer performance at the assessment stage was in good category (score $=78.25$ ). However, when putting attention in every aspect, in the learning assessment stage, there were still aspects in good enough category (score $=70$ ), namely aspect numbers 3 and 5. Aspect number 3 was the aspect of correcting and returning assignments to students, and number 5 was the aspect of discussing the exam results with students.

Figure 5 showed that according to students, there were still many lecturers who gave assignments to students, but these tasks were not corrected and returned to students. Also, there were still many lecturers who did not discuss the exam results with students. The assessment was also able to be used to improve the learning process. Therefore, it was necessary to enhance aspects that are still in the good enough category.

\section{4) Lecturer Performance in Each Faculty}

Figure 6 provided information regarding the performance of UNY lecturers based on each of the faculties for each aspect. Based on Figure 6, it could be seen that overall of the performance of UNY lecturers for each faculty was in a good category. It was able to be seen in the scores obtained for each stage, both in planning, process, and assessment. All stages for all faculties had a score of more than 70 . 


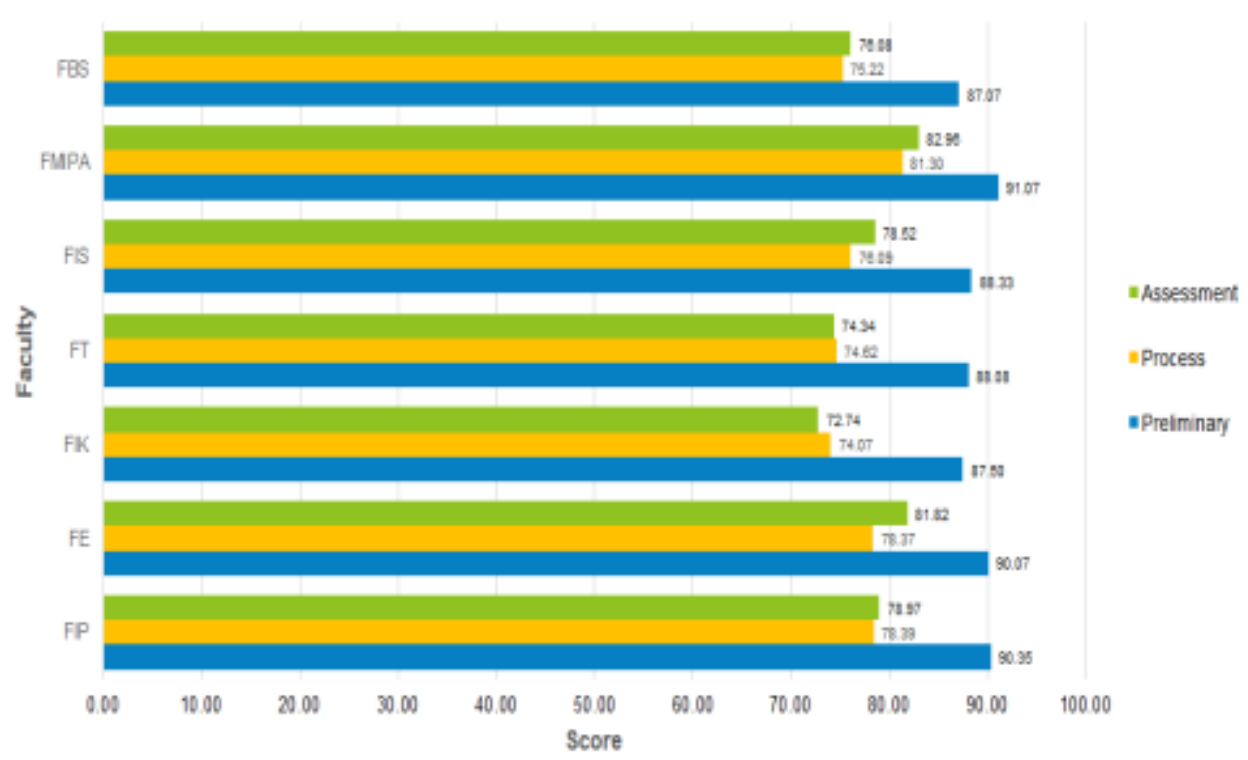

Figure 6

Lecturer performance in each faculty

Lecturer performance among faculties with each other had a short-range score. It meant that there were slight differences in the lecturer performance among faculties. Based on the results of MANOVA, it was found that at the preliminary or planning stage, there were no differences in each faculty, while at the process stage, there were significant differences among faculties. From Figure 6, it could also be concluded that the Faculty of Math and Science (FMIPA) was the faculty with the highest lecturer's performance score, while the Faculty of Sport Science (FIK) is the lowest score.The reason why FIK includes the lowest level is that the aspect of skill is more dominant in the assessment, so that it has different constraints compared to assessment for the cognitive aspect.

The distinction in the lecturer's performance might be caused by several factors. Hadiantini, Pandia, \& Kaburuan (2017) mentioned several factors that influenced lecturers' performance in conducting the learning process, such as work motivation, education, job satisfaction, perception of supervision, age, and years of service. According to Pramudyo, (2010). the factors that influence performance are motivation, competency, leadership, and work environment. Hamid (2013) acknowledged that the knowledge and skills of lecturers in conducting three dharma of higher education in Indonesia contributed to raising the lecturer's performance. Differences in lecturers' performance among the faculties could be caused by those factors.

\section{Computer Application for Lecturer Performance Evaluation}

The computer application for the lecturer performance evaluation in this research was developed from a manual instrument and scoring guide of lecturer performance 
evaluation. The results of research showed that it was important to enhance the professional teacher/educator in learning in various kinds of the fields by utilizing technology. (Chai, Hwee Ling Koh, \& Teo., 2019; Tican, \& Deniz, 2019; Ismail, Don, Husin, \& Khalid, 2018; Ajmain, Mahpuz, Rahman, \& Mohamad, 2019; Chou, Shen, Hsiao, \& Shen, 2018; Van Hong, Tuyen, \& Luong, 2018). Based on the opinion, the instrument or model developed was highly recommended to benefit technology by the conditions and developments of the times. One of them was the Internet-based lecture's performance evaluation model which has been developed. The Internet-based computer application developed in the research consisted of completing the respondent's identity, completing the teaching instrument, lecturer capacity, research, and community service. The developed computer application was Internet-based. This was aimed at facilitating the research respondents to access and complete the instrument of this lecturer performance evaluation. Besides, by using the Internet-based computer application, every response from the respondents was expected to be automatically saved in the system storage available in the Internet domain of the computer application. The computer-based instrument display is shown in Figure 7.

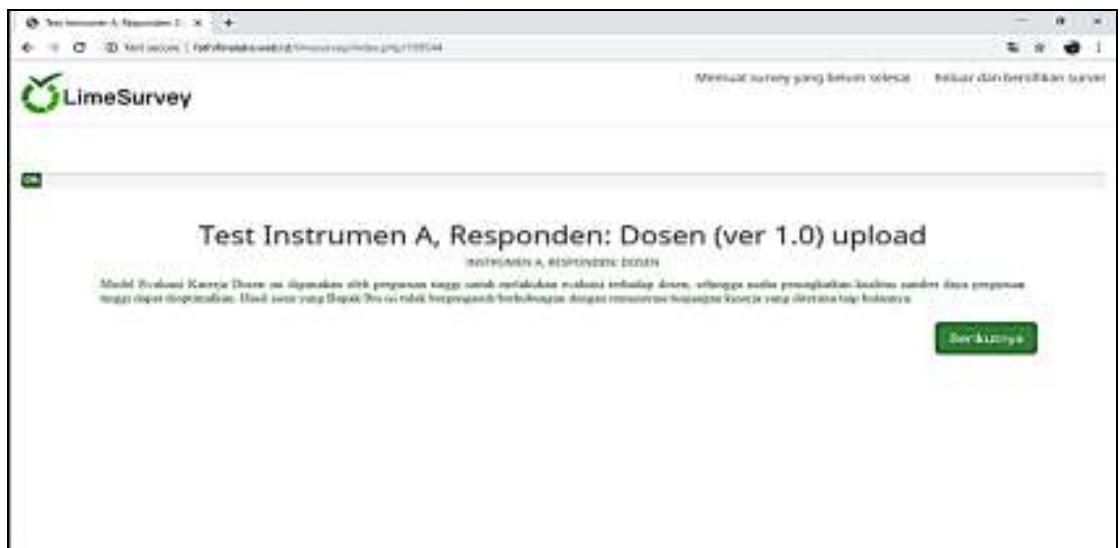

Figure 7

Display evaluation model after entering token

\section{Usage Guidelines of the Lecturer Performance Evaluation Model}

Lecturer performance evaluation was done by using four instruments presented in Table 2.

Table 2

Usage guidelines of the lecturer performance evaluation model

\begin{tabular}{llll}
\hline No & Instrument & Respondent & Number of Items \\
\hline 1 & Instrument A & Lecturer & 30 Item \\
\hline 2 & Instrument B & Students & 22 Item \\
\hline 3 & Instrument C & Academic staff of faculties & 4 Item \\
\hline 4 & Instrument D & Staff of the university's research center & 4 Item \\
\hline
\end{tabular}


Instrument A was the instrument completed by lecturers. Instrument B was the instrument measuring lecturer teaching performance. It was completed by students. Instrument $\mathrm{C}$ was the instrument completed by the academic staff of faculties. It consisted of four questions on lecturers' activities in the last three years. The activities included those of research, community service, and lecturers' activities as resource persons in seminars based on research reports, community service reports, and letters of an assignment. This instrument was to support the information on lecturers' activities obtained through Instrument A. Instrument D was the instrument completed by the staff of the university's research center. The data collected by using Instrument D were the data on lecturer performance in research and community service concerning SIMPPM (research and community service information system) and SIMLITABMAS (Name of Research and Community Service Information System) in the last three years. The data obtained through this instrument were used for determining lecturer performance in research. The data on community service was used for supporting the similar data collected by using Instruments A and C.

\section{DISCUSSION}

The research has managed to construct a model of the lecturer performance evaluation which was valid and reliable. The developed model consisted of a lecturer performance instrument, a user's manual, and a computer application of the lecturer performance evaluation. The lecturer performance instrument comprised an instrument for lecturer performance in teaching, research, community service, and lecturer capacity. These results were consistent with the results of the study of Miller, T. (2009) which said that formative computer-based assessment (CBA) was effective in supporting learning. CBA is indicated to be effective because the construct of the instrument is appropriate, fast and practical on the ground that the direct score can be seen after doing the test. This evaluation model can be used as a reference in evaluating lecturer performance as a consideration in improving lecturer performance holistically and sustainably.

The result of developing an instrument for lecturer performance evaluation in this research shows that lecturer performance is evaluated through four aspects: (1) teaching performance, (2) research performance, (3) community service performance, (4) lecturers' capacity. The result is under The Republic of Indonesia Law Number 14 the Year 2005 on Teachers and Lecturers, which states that the main duty of a lecturer is to teach, to do research, and to provide community service. Therefore, the developed instrument has covered all aspects of lecturer performance, and thus, the use of the instrument for evaluating lecturer performance will give a holistic evaluation result. This is in line with the needs for a performance evaluation according to Johnson, Lane, and Stone (Brennan.ed., 2006) who stated that a performance evaluation was an integral part of education reform so that acquiring holistic information on lecturer performance will be significant for the general improvement of education.

The evaluation model developed in this research consisted of the aspects of teaching, research, community service, and lecturer capacity which is in line with lecturers' professional duties, consisting of teaching, research, and community service. In this article, the focus only discussed the results of research in the field of teaching Cadez, 
Dimovski and Groff (2015) revealed that the workloads of most academicians were two main activities: research shows that lecturers are scientists, whereas teaching shows that lecturers are educators and have the task of transferring knowledge. Taylor (2007) also mentioned that teaching and research were the heart of higher education. Besides teaching and doing research, lecturers should be able to undertake community service. (Sanchez (2016) put forward that teaching and community empowerment were adherents not only to most academic positions but also to the planning of disciplines and professions. Therefore, it is to be true that the evaluation of lecturer performance is done partially not only to lecturers' obligation domain but also to all aspects of their responsibilities.

In this research, the researchers also measured the construct validity of the instrument of lecturer performance in teaching through the confirmatory factor analysis. The analysis shows that the three components of lecturer performance in teaching including planning, process, and assessment are proved to be supported by empirical data. Based on the results of research from Kusuma (2017) shows that competence (process and learning assessment), organizational culture, motivation have a significant effect on lecturer performance. This is in line with The Republic of Indonesia Law Number 14 the Year 2005 on Teachers and Lecturers which describes that in accomplishing their professional duties, lecturers are obliged to plan, implement teaching processes, and measure and evaluate their teaching results. The reliability estimate of the lecturer performance instrument in the field of teaching, which is done using Cronbach Alpha, resulted in a score of 0.844 , which shows that the instrument reliability is very high. According to Bernstein, I. H. (2010) the minimum standard for reliability was 0.7 . The higher reliability of the instrument showed that its reliability could be accounted for.

The result of the limited trial of the developed instrument shows that it managed to give information on lecturer performance well and complete (the complete element comprised of teaching, research, and community service). In the research finding section, it had been described that the developed instrument managed to map out a general profile of lecturer performance in four aspects holistically. The findings could be important information for making development programs and lecturer empowerment. It was related to the study done by Peleyeju and Ojebiyi (2013) which recommended that the management should guarantee a holistic and sustainable (continuous) evaluation of lecturer performance to improve the quality of lecturers and management in higher education holistically. Lecturer performance needs to be evaluated holistically so that the comprehensive data may be obtained and they can be used in making lecturers' development and empowerment programs.

The performance in the aspect of teaching showed that the highest achievement of lecturers was in the aspect of lecture program development which included making semester program plans, developing teaching materials, developing learning media. This showed that teaching staff with different functional positions still focused on developing matters related to process of learning in the classroom; they were related to teaching materials and lecture programs. The high performance of lecturers in terms of lecture program development was a blessing, but it did not mean that other aspects of their 
teaching could be put aside. Barber and Mourshed (2012) wrote that students' learning achievement began effective teachers. Barber and Mourshed even described that "students placed with high performing teachers will progress three times as fast as those placed with low performing teachers". Therefore, the high lecturer performance in lecture program development is expected to support the realization of effective teaching to increase students' learning achievement.

When they were related to their main job as lecturers, there was a correlation between lecturer performance and the quality of the teaching that they were doing. It associated with the research by Sharko, et.al (2015), which found that there was an effect of teachers' knowledge, up-to-date teaching materials, and classroom management on students' learning achievement. Muzenda (2013) also stated that knowledge of the subjects taught, teaching skill, lecturers' presence, and lecturers' attitude had a significant effect on students' academic achievement. In line with it, Marzano, Frontier, and Livingston (2011) revealed that the more the teachers' positive activities (such as teacher creativity in learning, the process according to the lesson plan, and other positive activities) in the classroom, the higher the students' learning achievement would be.

This research also found that lecturer performance in the aspect of lesson planning was in a very good and good category which was concluded based on the results of questionnaire data distributed to the students. The aspect of teaching implementation was mostly in a good category, although some were in a not good category. While in the aspect of evaluation, most were in a not very good category. All of these showed that there were teaching aspects that needed improvement. It related to Marzano (2011) who said that the more the teachers' positive activities in the classroom, the higher the students' learning achievement would be. Other experts, Barber and Mourshed (2012), write that students' learning achievement begins from effective teachers and principals. Therefore, the quality of teaching and evaluation implementation should be improved to increase student's achievement.

There is a lack of lecturer capacity with teaching experience, examination, supervising, becoming visiting lecturers in other universities, and publishing scientific articles in both national and internationally indexed journals (ISI Web of Science and Scopus). It associated with Bernadin (1995) who acknowledged that achievement was closely related to customers' satisfaction and the achievement of the organization strategic target so that lecturer performance which was in an unsatisfactory category could cause a decrease in society's satisfaction and interfere with the achievement of institution's strategic targets. The lack of teaching and testing experience might cause classroom teaching not optimal, this happened a lot to new lecturers who had not had an experience. Becoming visiting lecturers and making scientific publications was a very good medium of academic communication among academic society. The lecturer with poor performance in those two aspects showed that lecturers' involvement in the wider academic community needed improvement.

From the findings above, it could be noticed that the lecturer's performance evaluation was very important to get a lecturer's performance profile in fulfilling their professional 
duties and responsibilities. Academic staff of higher educational institutions the important role in the implementation of innovation in teaching processes (Jurgena \& Cedere, 2015). Lecturer performance should need supports in good academic competences because lecturers' academic competence has a significant effect on lecturer performance (Sukirno \& Siengthai, 2011). It is in line with the research by Long, Ibrahim, and Kowang (2014) which found that lecturers' competence is an important aspect that was related to students' satisfaction. For this reason, the result of the lecturer performance evaluation should be followed up through the programs which are oriented to lecturer performance improvement so that lecturers can be responsible for their profession well. One form of lecturer performance improvement was by developing innovative learning media such as computer-based learning, based on the results of research by Cramer, KM, Collins, KR, Snider, D., \& Fawcett, G. (2007) the virtual lecture hall was computer-based learning which was effective for increasing student learning achievement.

The computer application for lecturer performance evaluation developed in this research will be very useful for university leaders in the implementation of effective and efficient lecturer performance evaluation. It is Internet-based so that it can be used online, both for the instrument completion process and for the access and data analysis. The Internetbased lecturer performance evaluation enables lecturers to complete the questionnaire online, not restricted by time and place. The online application also enables to be designed to give the output of respondents' input accurately and quickly so that the needed result of the evaluation is obtained within a short time. The follow up of the evaluation result can be made immediately after the evaluation result is obtained. Therefore, the Internet-based evaluation application makes the evaluation model developed in this research be able to use effectively and efficiently. It associated with the opinion of Van der Kleij, Fabienne Michelle (2013) Computer-Based Assessment (CBA) is a form of assessment where students were given tests using computers. CBA was very useful for knowing and identifying differences in student output, to determine the characteristics of each student regarding the type of answer, level, and time used. Everything can be calculated in a relatively short time.

In addition to the computer application, the usage guidelines of the lecturer performance evaluation model developed in this research will be helpful in the implementation of lecturer performance evaluation. The four developed instruments including Instrument A, Instrument B, Instrument C, and Instrument D are the key instruments for obtaining the lecturer's performance profile. The instruments are the concrete realization of the developed evaluation model which is directly distributed to the respondents to gather data. Therefore, the evaluation model developed in this research is conceptual but it is operationally completed with the user's manual and its instrumentation.

\section{CONCLUSION}

Based on the results of the study, it can be concluded that the lecturer's performance evaluation model in learning that includes planning, process, and assessment is valid and reliable. Valid is concluded based on the results of expert assessments that are analyzed using the Aiken formula and the results of the analysis using Confirmatory Factor 
Analysis (CFA), while reliability is proven based on the estimation results using Cronbach Alpha which shows the lecturer performance instruments are reliable. The results of the performance evaluation of lecturers using a model that has been developed in a good category. Based on the results of MANOVA, it was found that at the preliminary or planning stage there were no differences in each faculty, while at the process and assessment stage there were significant differences in each faculty. The results of this study can be used as a ground base in preparing a program for improving lecturer performance at faculties that have a low score in the aspects of the process and assessment.

Based on the result and conclusion of the study described above, it is offered several recommendations in the following. (1) The lecturer's performance evaluation model which has been developed can be used to conduct the annual evaluation held by the university in order to improve the quality of lecturer in learning and it has been valid and reliable; (2) The chief of the university can give a reward to the faculty with the highest score in lecturer's performance and provide the special development to the faculty with the lowest score in lecturer's performance as an effort to build the quality of performance; (3) The performance of lecturer in learning needs to be improved so that the lecturer's performances in the aspect of preparation, process, and assessment are in the high category.

\section{REFERENCE}

Abrami, P.C. et al. (2015). Strategies for Teaching Students to Think Critically A MetaAnalysis. Review Educational and Research Journal. Concordia University Canada: Sage.Pub. AERA.

Ajmain, M. T., Mahpuz, A. N. A., Rahman, S. N. H. A., \& Mohamad, A. M. (2019). Industrial Revolution 4.0: Innovation and Challenges of Islamic Education Teachers in Teaching. BITARA International Journal of Civilizational Studies and Human Sciences, 2(1), 38-47.

Armstrong, M. (2000). Performance management. London: Kogan Page.

Aoun, J.E. (2017). Higher education in the age of artificial intelliegence. London: The MIT Press.

Barber, M \& Mourshed, M. (2012). Professional development international. New York: Pearson.

Bernadin, H. K., Kane, J. S., Ross, S., Spina, J.D. \& Johnson,D. L. (1995) 'Performance appraisal design, development and implementation', in G. R. Ferris, S. D. Rosen and D. J. Barnum (eds), Handbook of human resource management. Cambridge,MA: Blackwell.

Bernstein, I. H. (2010). Psychometric theory. Tata McGraw-Hill Education. 
Blankenau, W., Dorhout, P., \& Mason, A.C. (2014). Annual Evaluation Guidelines, Promotion, and Tenure Guidelines, Post-Tenure Review. Kansas: Department of Economics, Kansas State University

Brennan, R.L. (Eds) (2006). Educational measurement $\left(4^{\text {th }} e d\right)$. Westport: Praeger Publishing of Greenwod Publishing Group. Inc.

Brown, G.T.L., Irving, S.E., \& Keegan, P.J. (2014). An Introduction to Educational Assessment, Measurement, and Evaluation: Improving the quality of teacher-based assessment ( $3^{\text {rd }}$ Edition). New Zealand: Dunmore Publishing Limited.

Cadez, S., Dimovski, V., \& Groff, M.Z. (2017). Research, teaching, and performance evaluation in academia: the salience of quality. Studies in Higher Education, 42(8), 1455-1473. https://doi.org/10.1080/03075079.2015.1104659

Chai, C. S., Hwee Ling Koh, J., \& Teo, Y. H. (2019). Enhancing and modeling teachers' design beliefs and efficacy of technological pedagogical content knowledge for $21 \mathrm{st}$ century quality learning. Journal of Educational Computing Research, 57(2), 360-384.

Chou, C. M., Shen, C. H., Hsiao, H. C., \& Shen, T. C. (2018). Industry 4.0 Manpower and Its Teaching Connotation in Technical and Vocational Education: Adjust 107 Curriculum Reform. International Journal of Psychology and Educational Studies, 5(1), 9-14.

Cramer, K. M., Collins, K. R., Snider, D., \& Fawcett, G. (2007). The virtual lecture hall: Utilisation, effectiveness and student perceptions. British Journal of Educational Technology, 38(1), 106-115.

Dzelzkaleja, L. \& Kapenieks, J. 2018. Contradictions in Higher Education. Journal of Teacher Education for Sustainability, Volume 20 Issue 1, pp. 124 - 144, DOI: 10.2478/jtes-2018-0008

Earl, L., Hargreaves, A., \& Schmidt, M. (2002). Perspective on Reform. American Educational Research Journal, Spring 2002, Vol. 39. No. 1.

Geldhof, G. J., Preacher, K. J., \& Zyphur, M. J. (2014). Reliability estimation in a multilevel confirmatory factor analysis framework. Psychological Methods, 19(1), 72.

Jones, J., Jenkin, M., \& Lord, S. (2006). Developing effective teacher performance. California: SAGE Publishing Company.

Jurgena, I. \& Cedere, D. (2015). Innovative and Traditional Elements in the Work of Academic Staff: The Views of Pre-service Teachers. Journal of Teacher Education for Sustainability, Volume 19 Issue 1, pp. 22 - 42 DOI: 10.1515/jtes-2015-0012

Hadiantini, R., Prayanta, S., \& Robert, E. (2017). Lecturer performance factors in private universities in Bandung City. International Journal of Human Resource Studies, 7(4).

Hamid, S. (2013). Lecturers' performance and technology at private higher education in South Sulawesi Indonesia. Procedia-Social and Behavioral Sciences, 83, 580-584. 
Harisantoso, J. (2012). Pengukuran kinerja dosen melalui EKD (Evaluasi Kinerja Dosen) STKIP PGRI Situbondo berdasarkan persepsi mahasiswa. Sainteks, 9(2).

Ismail, S. N., Don, Y., Husin, F., \& Khalid, R. (2018). Instructional Leadership and Teachers' Functional Competency across the 21st Century Learning. International Journal of Instruction, 11(3), 135-152

Jones, Anne. (2018). Vocational Education for the Twenty-First Century. The University of Melbourne

Kusuma, A. H. P. (2017). Pengaruh kompetensi, budaya organisasi dan motivasi terhadap kinerja dosen perguruan tinggi swasta di kota makassar. Economics Bosowa, 3(8), 88-100.

Long, C. S., Ibrahim, Z., \& Kowang, T. O. (2014). An Analysis on the Relationship between Lecturers' Competencies and Students' Satisfaction. International Education Studies, 7(1), 37-46.

Marzano, R.J. Frontier, T., Livingston, D. (2011). Effective supervision. Alexandria: ASCD.

Mohammadi, M. \& Moradi, K. (2017). Exploring Change in EFL Teachers Perceptions of Professional Development. Journal of Teacher Education for Sustainability, Volume 19 Issue 1, pp. 22 - 42, DOI: 10.1515/jtes-2017-0002

Miller, T. (2009). Formative computer-based assessment in higher education: The effectiveness of feedback in supporting student learning. Assessment \& Evaluation in Higher Education, 34(2), 181-192.

Muzenda, A. (2013). Lecturers' Competences and Students' Academic Performance. International Journal of Humanities and Social Science Invention. Volume 3 Issue 1, January 2013, pp.06-13.

Nurdiyanto, H., \& Vem, E. (2016). Performance Evaluation Decision Support System Using The Lecturer Analytical Hierarchy Process (Case Study: Stmik Dharma Wacana Metro). Jurnal Teknologi Informasi Magister, 1(01), 1-16.

Nunnally, J.C. (1964). Educational mmeasuremment and evaluation. New York: McGraw-Hill.

Peleyeju, J.O. \& Ojebiyi, O.A. (2013). Lecturers' Performance Appraisal and Total Quality Management of Public Universities in South-Western Nigeria. British Journal of Education. Vol.1, No.2, pp.41-47, December 2013.

Pramudyo, A. (2010). Analisis faktor-faktor yang mempengaruhi kinerja dosen negeri pada kopertis Wilayah V Yogyakarta. JBTI: Jurnal Bisnis: Teori dan Implementasi, 1(1), 1-11.

Reeves, D.B. (2010). Transforming professional development into student results. Alexandria: ASCD. 
RI, K. P. N. (2019). Undang-Undang RI No. 14 Tahun 2005 tentang Guru dan Dosen.

Sanchez, T. W. (2017). Faculty Performance Evaluation Using Citation Analysis: An Update. Journal of Planning Education and Research, 37(1), 83-94. https://doi.org/10.1177/0739456X16633500.

Sharko, D.A., Sharko, G, Demi, B, Baholli, B. (2015). "UET Online Lecturer Performance Evaluation System". Journal of educational and social research, Vol 5, No. 2, May 2015. Rome: MCSER, Publishing.

Sok-Foon, Y., Sze-Yin, J. H., \& Yin-Fah, B. C. (2012). Student evaluation of lecturer performance among private university students. Canadian Social Science, 8(4), 238243.

Suherman, A., Mulyasana, D., \& Mulyasa, E. (2019). Faktor-Faktor Determinan Terhadap Kinerja Dosen Dalam Meningkatkan Mutu Layanan Akademik Pendidikan Tinggi. Kajian Manajemen Pendidikan, 1(2), 1-10.

Sumardjoko, B. (2010). Faktor-faktor determinan peran dosen dalam penjaminan mutu perguruan tinggi. Jurnal Cakrawala Pendidikan, 3(3).

Sukirno \& Siengthai, S. (2011). Does participative decision making affect lecturer performance in higher education? International Journal of Educational Management, Vol. 25 Iss: 5, pp.494 - 508.

Tahir, M., Haming, M., \& Bijaang, J. (2018). Organizational communication effect on lecturer performance in Muhammadiyah University of Makassar.

Taylor, J. (2007). The teaching: research nexus: A model for institutional management. Higher Education, 54(6), 867-884. https://doi.org/10.1007/s10734-006-9029-1.

Tican, C., \& Deniz, S. (2019). Pre-service Teachers' Opinions about the Use of 21st Century Learner and 21st Century Teacher Skills. European Journal of Educational Research, 8(1), 181-197.

Van Hong, B., Tuyen, T., \& Luong, N. T. (2018). Teaching Capacity of Technology Teachers: Applying in the Training Program of Technology Teacher in Vietnam. American Journal of Educational Research, 6(12), 1662-1667.

Van der Kleij, Fabienne Michelle (2013). Computer-based feedback in formative assessment. PhD Thesis University of Twente, Enschede, the Netherlands. - Met een samenvatting in het Nederlands. 